\title{
Creating a Web-based Course-Book on Revitalization of the Sampyong for University Students
}

\author{
Nurhayati $^{1}$, Tono Suwartono ${ }^{2, *}$, Agus Saripudin ${ }^{1}$ \\ ${ }^{1}$ Department of Language and Arts Education, Faculty of Teacher Training and Education, Universitas Sriwijaya, Indonesia \\ ${ }^{2}$ Department of English Language Teaching, Faculty of Teacher Training and Education, Universitas Muhammadiyah Purwokerto, \\ Indonesia
}

Received August 13, 2020; Revised August 17, 2020; Accepted November 12, 2020

\section{Cite This Paper in the following Citation Styles}

(a): [1] Nurhayati, Tono Suwartono, Agus Saripudin, "Creating a Web-based Course-Book on Revitalization of the Sampyong for University Students," Universal Journal of Educational Research, Vol. 8, No. 12, pp. 6790 - 6797, 2020. DOI: 10.13189/ujer.2020.081245.

(b): Nurhayati, Tono Suwartono, Agus Saripudin (2020). Creating a Web-based Course-Book on Revitalization of the Sampyong for University Students. Universal Journal of Educational Research, 8(12), 6790 - 6797. DOI: 10.13189/ujer.2020.081245.

Copyright $\bigcirc 2020$ by authors, all rights reserved. Authors agree that this article remains permanently open access under the terms of the Creative Commons Attribution License 4.0 International License

\begin{abstract}
This study aimed to find out the students' needs for a web-based course-book, describe the validation result from the experts regarding the course book being developed, figure out the practicality aspect of the course book, and describe the effectiveness of course book. The study employed a mixed version of Plomp's and Tessmer's research and development $(\mathrm{R} \& \mathrm{D})$ major procedures. The R\&D procedure involved analyzing students' need, designing and producing a prototype of a web-based course-book, and evaluating the prototype including expert validation, one-to-one evaluation, small group evaluation, and field testing. Questionnaire was administered to investigate the students' needs. One-to-one evaluation and small group evaluation were conducted to examine the practicality aspect of the course book being developed. Test was administered to assess the effectiveness of the course-book. Results of the analysis have shown that the students needed a web-based course-book. The course-book consisted of materials, comprehension questions, bibliography, glossary, author profiles, the Sampyong videos and photos, and logout menus. The expert validation average score was 4.27 (out of 5), belonging to category "good". Based on one-to-one and small group evaluation, the web-based course-book was considered practical for university students. The objective test administered revealed that the students' achievement significantly increased from the average scores 66 (pre-test) to 79 (post-test).
\end{abstract}

Keywords Course-Book, Web-Based, Revitalization, Martial Arts, Sampyong

\section{Introduction}

The performing art of Sampyong, pronounced as /sımpjoy/, is a traditional martial art performed by the community in the town of Indramayu, West Java, Indonesia. This martial art is also popular in other regions nearby, such as Majalengka and Cirebon. In Indramayu the Sampyong has been known since 1433 while gaining popularity in Majalengka about the 1600s. In the 1970s, the Sampyong was still popular among the community because it was performed for traditional events, such as wedding ceremony, circumcision, and harvest time. Over time, the Sampyong has been rarely performed and shifted its existence function for entertainment only. In other words, the Sampyong has been abandoned by the community, particularly the young generation [1].

An initial survey with 100 young people in Indramayu showed that only $16 \%$ of them have ever watched the Sampyong [2]. It is obvious that the Sampyong has nearly reached its extinction [3]. The Focus Group Discussion on June $10^{\text {th }}, 2018$ in Indramayu Regency arrived at a conclusion that the people of Indramayu have caught the signs of Sampyong's extinction based on the fact that it has been rarely performed. As a result, the people would hope 
that several efforts were taken for maintaining its existence among the young generation, particularly university students. This is in line with the view that the involvement of the young generation is essential for maintaining traditions [4], [5], [6]. Therefore, one of the strategies to preserve the Sampyong is by involving the young generation.

The most effective way to maintain tradition is through teaching [7] as the case of Cambodia where people maintained their traditional music genre through the teaching-learning process [8]. Similar measures were also taken through the Dulmuluk performing art by teaching it in the university [9]. To preserve the Sampyong, the authors as the then-researchers have introduced it as a major subject in Pendidikan dan Pembelajaran Jasmani (Physical Education and Teaching Course), within the topic of traditional games. This subject did not have a course-book related to the Sampyong. Therefore, developing a course-book for this became necessary.

The course-book is highly important in the teaching-learning process. The course-book can make the teaching more effective and efficient [10], [11], [12], [13], [14], [15], [16], [17]. Nowadays, there has been a rapid growth in the use of websites and information technology (IT) to support the teaching process [18], [19], [20], [21], [22], [23], [24]. It is also stated that online learning gives more significant contribution to the teaching practices, compared to the traditional system. An attempt to improve students' interests in the teaching-learning process through the use of websites has been made by Oktaria et al. [25]. Online learning has a positive effect on student learning engagement, critical thinking, intercultural sensitivity, and interpersonal skills [26], [27], [28]. It can be said that the use of website in the teaching-learning process can improve both cognitive ability and affective aspects at the same time.

The purposes of the present study were: to identify the students' needs for a web-based course-book on the revitalization of the Sampyong, to validate the coursebook's quality based on the expert judgment, to elucidate the practicality aspect of the web-based course-book, and to determine the effectiveness of the web-based course-book. This research is expected to benefit anyone who will learn the Sampyong through a web-based course-book.

\section{Materials and Methods}

This study employed a mixed version of Plomp's [29] and Tessmer's [30] R\&D major procedures, which involve three major steps. The first step was assessment of the needs of the course-book. The second step was designing and production of the web-based course-book based on the need assessment. Then, evaluation of the course-book was the third step of the study.

\subsection{Need Assessment of a Course-Book on Sampyong}

Need assessment was administered by giving a questionnaire to 40 students who attended the Physical Education Course in the Department of Physical, Health, and Recreation Education, Faculty of Teacher Training and Education, Universitas Sriwijaya. The questionnaire was developed by the authors as the then-researchers and validated by Professor Mulyadi Eko Purnomo of Universitas Sriwijaya. It comprised a number of closed-ended questions as well as open-ended questions related to the need for a course-book and its special topics regarding the Sampyong.

\subsection{Designing and Production of the Web-Based Course-Book on the Basis of the Previous Analysis}

The website was created by a website developer from the Indonesian Telecommunications Company and it goes with these following menus: user manuals, learning objectives, materials, questionnaires, bibliography, glossary, the author profile, performance video, documented photos, and logout menu.

\subsection{Evaluation of the Web-based Course-book}

The first evaluation was expert review. Expert reviews were conducted by four experts: two content experts (Dr. Tahidin from Universitas Wiralodra, Indramayu and Dr. Didi Suhendi from Universitas Sriwijaya), one linguist (Dr. Subadiyono from the Department of Language and Arts Education, Universitas Sriwijaya), and one media expert (Novri Hadinata from Faculty of Computer Science, Universitas Bina Darma in Palembang). The reviewers or validators were invited to give their thoughts, opinions, and views of the course-book being developed, especially the content, language, and media. To finalize their validation task, each validator was requested to complete a 5-point scale rating ( $1=$ very invalid, $2=$ invalid, $3=$ valid enough, $4=$ valid, and $5=$ very valid).

The next evaluation was one-to-one evaluation. This evaluation was carried out to assess the practicality of the course-book being developed. The evaluation was done through questionnaires with a 1 to 5 rating scale to three participants from different proficiency levels: low (1 student), intermediate (1 student), and advanced (1 student). The category determination was based on the student Grade Point Average (see Tessmer aforementioned). Besides, the one-to-one evaluation was done to obtain the data related to the clarity of instructions in the course-book being developed, the implication of the course-book to the students, and the suitability of the course-book in the context of performance.

The clarity of instructions covered some components, such as vocabulary constraints, sentence and message complexity, clarity in the introduction, conclusion, examples, illustrations, directions, reviews, summary, 
transition, content sequences, and balance of proportion in the book. On the other hand, the impact on the learner's aspect consisted of meaningful information, simplicity, satisfaction, and clarity of the test. Besides, the aspect of performance comprised content suitability, motivation, when and how to use, tools to use, and problem-solving.

Another evaluation was small group evaluation. Twelve students participated in this evaluation for the purpose of determining of the practicality of the course-book. The participants were representative of low, intermediate, and advanced levels of students. Small-group evaluation was conducted to determine whether: (1) the materials in the developed course-book can attract the students' attention; (2) the objectives, concept reviews, and the available activities in the developed course-book could help students understand Sampyong and (3) the readability of the materials in the developed course-book is high.

The last activity in the formative evaluation was field testing to examine the effectiveness of the developed course-book. In this field testing, an experiment was carried out using a one-group pre-test and post-test design with 40 students involved as participants. The students were sitting at the third-semester in the Department of Physical and Health Education at Universitas Sriwijaya. The instrument for collecting data was a 28-item multiple-choice test. And, the test was administered twice: before and after the students used the developed course-book.

To analyze the data on test result, SPSS version 21 (IBM, USA) was used to describe the data gained from pretest and posttest through a paired sample t-test. This paired sample t-test was to examine whether there was any significant difference in average score between before and after the students used the developed course-book.

\section{Research Result and Discussion}

\subsection{Students' Need Analysis}

Based on the questionnaire result, it was found that $85 \%$ of the 40 participants stated that they needed the course-book on Sampyong. It might be due to the unavailability of the course-books on Sampyong. Moreover, $78 \%$ of them wanted it based on the website or online so that they could download it and then read the materials anytime and anywhere. With regard to material aspect, $85 \%$ of the students wanted the Sampyong history. While $75 \%$ wanted the Sampyong martial arts techniques. Last, $88 \%$ needed the Sampyong video tutorials. Concerning evaluation aspect, $80 \%$ of the participants stated that both multiple-choice and the essay tests were required to test performance. The performance in this context refers to giving a Sampyong demonstration in front of the class or even in the public. Those comments and suggestions were accommodated in designing the prototype of the web-based course-book.

\subsection{Design of the Web-Based Course-Book}

The course-book was designed using a web-enhanced course model that utilizes the internet to improve teaching quality (see Figure 1). The course-book consisted of seven chapters, namely: introduction with the explanations of the Sampyong martial arts of old paradigm and new paradigm; the nature of the Sampyong with the definition of the Sampyong; the Sampyong history, and the Sampyong equipment; the Rules of the Sampyong, such as in the competition, equipment for competition, and the conditions for the Sampyong performance; the Sampyong as Sport which includes the definition of Sampyong as a sport and the review of Sampyong from sports perspective; the Sampyong Performing Art (Sampyong performances and its supporting facilities and infrastructure); the Supporting Components, which include the physical components, durability, and the nature of speed of the Sampyong; and the Psychological Components, which include the psychological components, moral nature, and motivation of the Sampyong. 


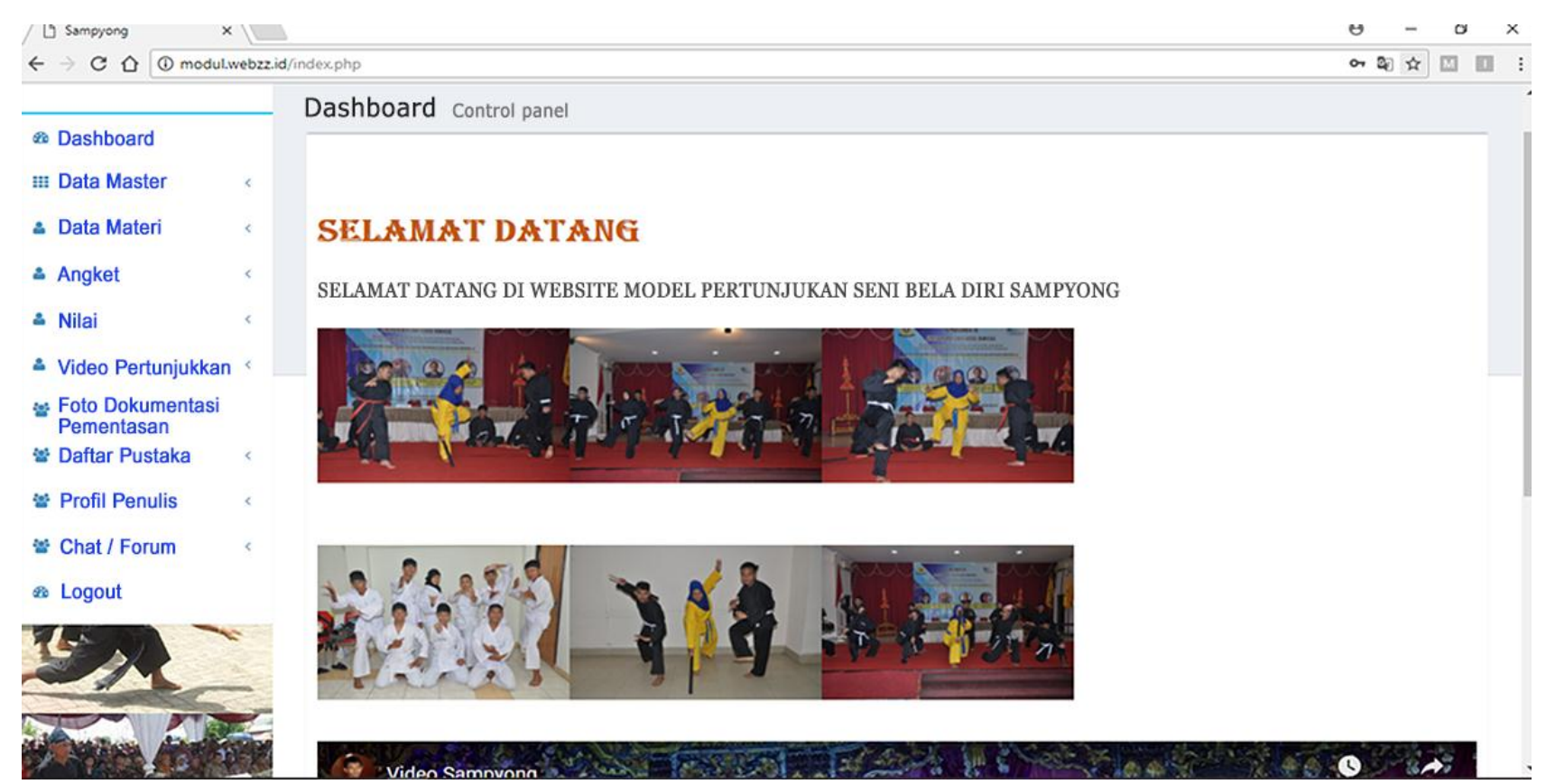

Figure 1. The Sampyong course-book website (https://www.modul.webzz.id)

\subsection{Expert's Validation}

Out of the 13 components in content aspect, i.e.: clarity of instructional objectives; relevance of materials to the objectives; organization of materials (coherence, sequence, logics, systematicity, simplicity); relevance to students' development; appropriateness of the materials, text models, and the exercises; motivation elements (verbal) and attractiveness (color and images) reached the maximum score of 5. Appropriateness of the media to learning objectives and materials gained 4.5. Relevance of the exercises to the learning objectives and materials gained 4 . Also, aspects of novelty; scope; and depth of the prototyped course-book gained $4,4.5$, and 4.5 , respectively. Last, the aspect of references gained 3.5. The total score was 60 with 4.6 being the average score, which means that the course-book was appropriate and valid for use (Table $1)$.

Table 1. Expert validation of the developed course-book

\begin{tabular}{ccccc}
\hline No & Aspect & $\begin{array}{c}\text { Tot } \\
\text { Score }\end{array}$ & Average & Category \\
\hline 1 & Content & 60 & 4.6 & valid \\
\hline 2 & Language & 45 & 4.09 & valid \\
\hline 3 & Media & 57 & 4.1 & valid \\
\hline
\end{tabular}

From the language aspect (14 components), the developed course-book could be categorized as valid and appropriate for use with a total score of 45 and average score of 4.09 (Table 1). Two aspects, namely accuracy of diction and clarity of the language of directions, gained the maximum score of 5. Some aspects, i.e. accuracy of spelling; accuracy in using samples, non-samples, metaphors, analogy, and others; communicativeness of the language style; and suitability of the language style with the students' learning needs; readability; grammatical accuracy, accuracy in vocabulary selection averaged 4 . Meanwhile, language appropriateness, sentence cohesion, and paragraph cohesions averaged 4,4 , and 3 , respectively.

Based on review of the media aspect, the prototyped course-book can be classified as valid and appropriate for use, gaining a total score of 57 with the average score 4.1 (Table 1). Appropriateness of size and font types; appropriateness of graphics (tables, diagrams, etc.) to instructional objectives and materials; appropriateness of the visuals (pictures, photos, and sketches) to the objectives and materials; quality of graphs ( tables, diagrams, charts); quality of the overall visuals and the consistency in using font, color, illustrations, icons, and others scored 4 on the scale. Meanwhile, the accuracy in font selection; color selection; illustrations; and icons gained 4, 3, 4 and 4 respectively. On the other hand, attractiveness; the organization of presentation; and interactiveness (involving stimulus-responses) scored 5, 5, and 4 respectively. Last, the aspect of navigation on the developed course-book scored 4 on the scale.

\section{One-to-One Evaluation}

Based on the one-to-one evaluation, clarity of instructions or directions had the highest score 4.8 out of the maximum 5, followed by impact on learners (4.2) at the second place, and performance as the lowest with 3.83 (Figure 2). It can be concluded that the developed course-book could be categorized as practical for use by the students. 


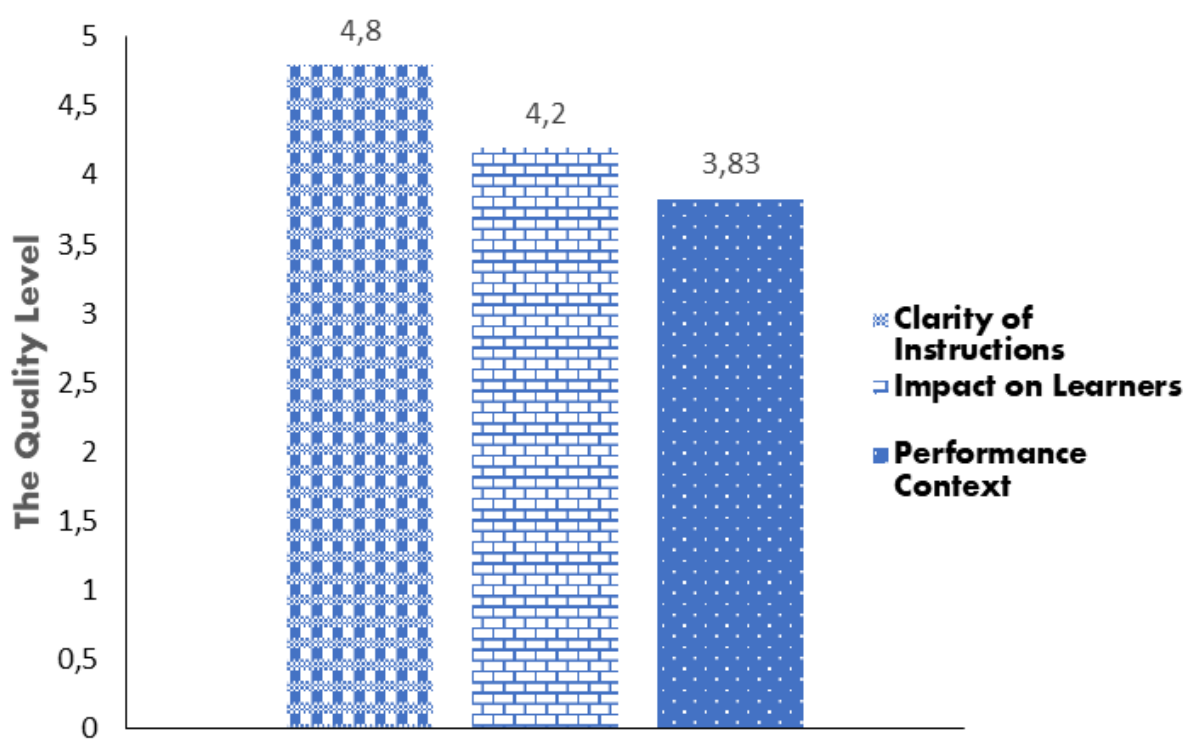

Figure 2. One-to-one evaluation by 3 participants to the course-book

\section{Small Group Evaluation}

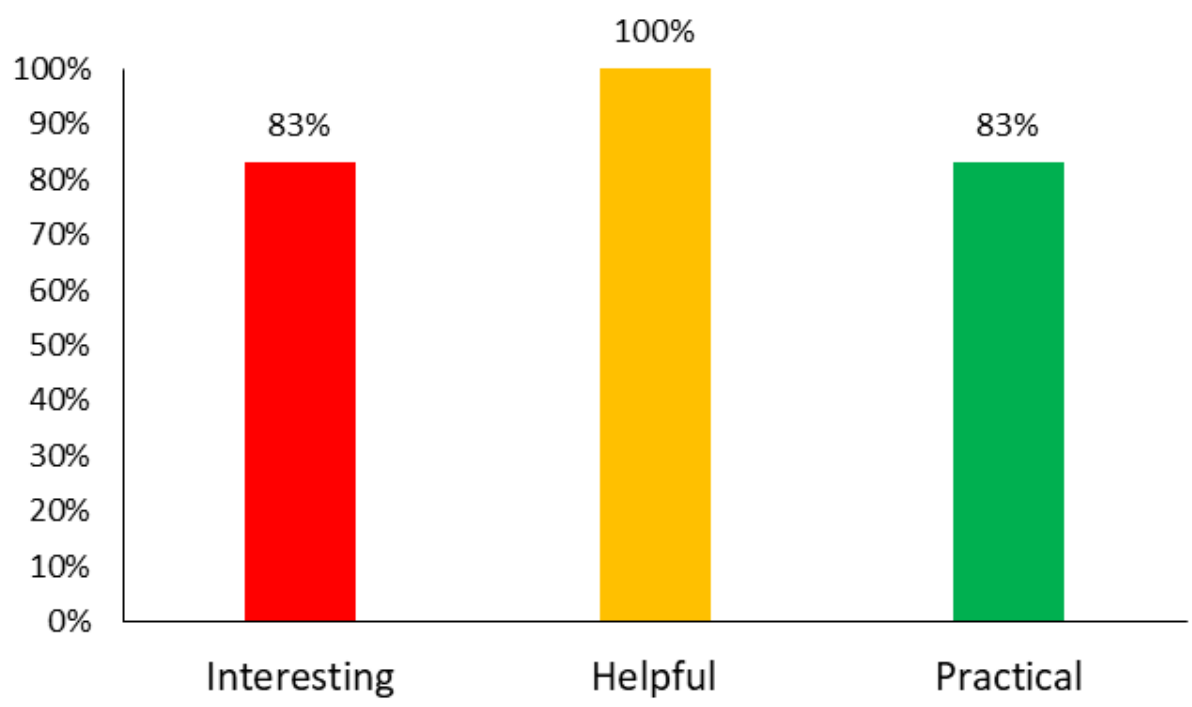

Figure 3. Small group evaluation on the developed course-book

\section{Small-Group Evaluation}

As many as $83 \%$ of the participants stated that the developed course-book was interesting. Further, $100 \%$ of them found that the learning objectives, materials, and exercises in the developed course-book could help them understand the Sampyong. Last, $83 \%$ of the participants said that they found high clarity in both the materials and learning activities of the developed course-book (Figure 3).

\section{Field Testing}

From the field testing, it was found that the pretest score was 66 , while the posttest score was 79 . The paired sample $\mathrm{t}$-test indicated that there was a significant gain $(\mathrm{p}<0.05)$ before and after the students used the developed web-based course-book, meaning that the developed web-based course-book was effective (Figure 4). 


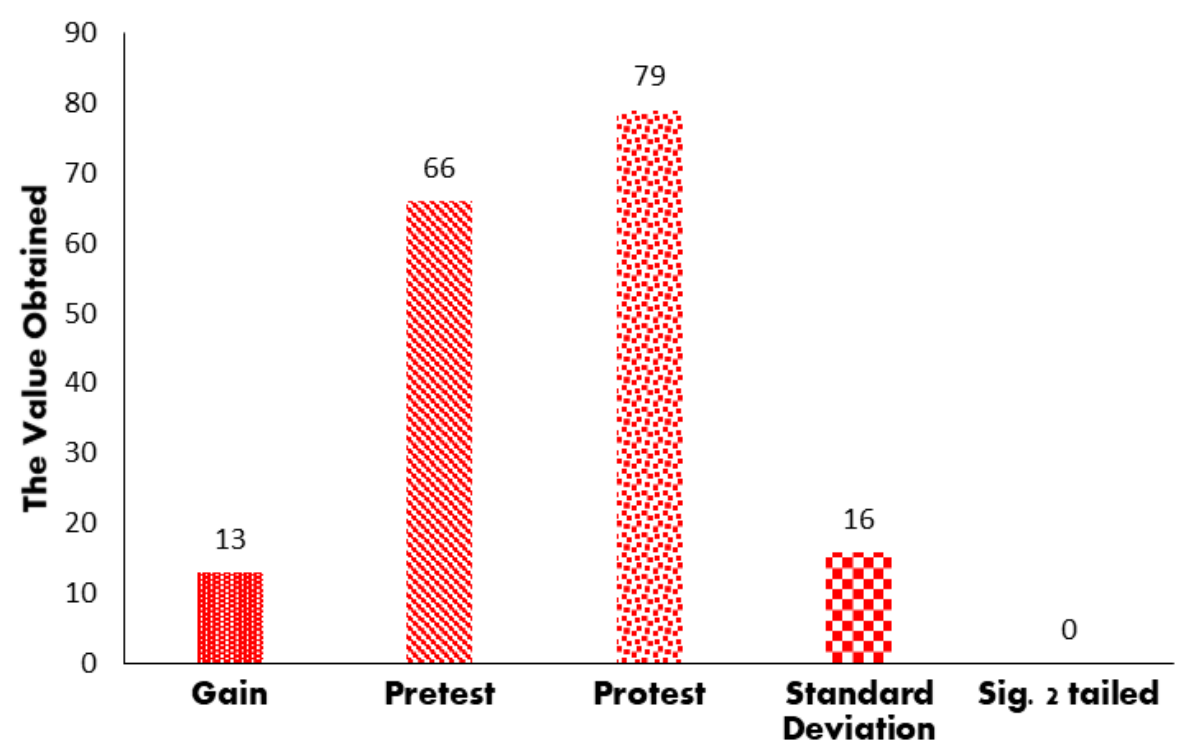

Figure 4. Field testing result of the developed course-book

The developed web-based course-book was designed as a major teaching material which will be used in the Pembelajaran Pendidikan Jasmani (Physical Education Course) at Faculty of Teacher Training and Education, Universitas Sriwijaya. This web-based course-book was a self-study book that could be used without intense guidance from the lecturers. Therefore, it serves as a tool to introduce the Sampyong to university students as part of the young generation who are expected to have a pivotal role in maintaining the Sampyong. Besides, they are teacher candidates, who can introduce it to school students after they work as teachers upon graduation from their teacher training college.

Results of the small group evaluation have shown that the developed web-based course-book was practically interesting to $83 \%$ of the participants. According to them, the book was designed based on IT development, applying online learning system. This is consistent with the result of studies [31] and [32] which found that the use of a website in the teaching process can improve students' interest.

Moreover, this course-book also offers practicality in use by the users. They only need cell phones or a laptop with an internet connection to access the course-book. Therefore, the materials can easily be accessed anytime and anywhere. In addition, students or any users can learn the materials in accordance with their own learning pace. Utilizing a website could enable the students to learn anytime, anywhere, and pace their own growths [33], [34].

Availability of the Sampyong videos also helps to students to get a detailed perception in learning it. The course-book also presents a set of rules and regulations in Sampyong and provides a room for student-teacher/lecturer discussion. The discussion can be held with regard to the materials of Sampyong that must be sufficiently explored or studied.

Even though the course-book was designed with all efforts and full awareness of many criteria in its development, it may unavoidably come with some weaknesses [35]. It is stated that the absence of the menu for 'forget password' is something that had to be solved. The menu was advisably needed. Some of the participants complained about the insufficient explanation of the course-book, especially on the rules of Sampyong. For example, it was not clearly mentioned why the rattan strike had to be only on the calves and was not allowed to hit other parts of the body.

The field testing showed the increase in the students' skill of practicing the art of Sampyong after using the course-book. The increase could be due to the fact that the students know the Sampyong better as the course-book gives them guidance, learning goals, materials, evaluation, grades, video performances, glossary, documented photos, and the discussion forums in the form of student-teacher and student-student discussions.

A similar result reported from a study which applied web-based learning showed that students' achievement and motivation highly improved after utilizing web-based learning [36]. Other researchers conducted longitudinal research for both undergraduate and graduate students to examine the use of web-based learning [37]. The findings suggested that the learning process was more effective and the students were more satisfied when the web-based learning was included.

The results of this study will likely benefit the Sampyong teachers. The Sampyong course-book contains a lot of aspects of Sampyong, such as the old and new paradigm, nature, rules, supporting components and the psychological components of Sampyong, as well as Sampyong as a sport and a performing art. Besides, this web-based course-book has a full video of a Sampyong performance covering the slow-motion and natural movement as a result of revitalization. After that, the course-book also has evaluation questions about Sampyong for users. 


\section{Conclusion}

Results of the need analysis have shown that the students needed a web-based course-book. They needed to possess knowledge concerning the history of Sampyong, to master the techniques of Sampyong martial arts, the rules of Sampyong, and to have a collection of video performances of Sampyong martial arts.

The next attempt was the designing of the web-based course-book of Sampyong which consisted of manuals website, the learning objectives, materials, questionnaire, bibliography, glossary, the author profile, video performance, documented photos, and logout menu.

Results from the expert's validation showed that the web-based course-book was valid and appropriate for students. Based on the one-to-one evaluation and small group evaluation, the developed web-based course-book could be categorized as practical for use. Finally, the result of field testing has shown that the course-book was effective.

Suggestions can be stated based on the research findings. This web-based course-book can be used by anyone who wants to learn Sampyong. The Sampyong is expected to be one of Indonesia's icons as it originally came from Indramayu Regency and Majalengka Regency, West Java, Indonesia. As a consequence, some efforts should be taken to preserve it, for example, by positioning Sampyong as a subject in the local curriculum. Last, this current research was evaluated using a low validity experimental research design, i.e. one group experimental design without control. It is highly advisable to conduct a two-group experimental research design that includes a control group to get more accurate research results.

\section{Acknowledgments}

We are grateful to Directorate of Research and Community Service, Directorate General for Strengthening Research and Development, the Ministry of Research, Technology and Higher Education for funding the research project which this work was based on. We are greatly indebted to Office of the Youth Affairs and Sports in Indramayu, West Java and Office of Culture and Tourism in the same Regency for giving us permission and valuable support regarding the research. We also express our sincere appreciation to all students participating in the research for spending their precious time on the project.

\section{REFERENCES}

[1] L. Ratnawati, Nurhayati, Sukirno, "The revitalization of sampyong performing art: An attempt of preservation and exploration on the values of local wisdom," The 28th International Conference on Literature (ICoL) XXVIII, pp.
891-898, 2019.

[2] Nurhayati, S. Sukirno, L. Ratnawati, "Sustainability of sampyong: Revitalization effort of a performance art to a martial art," The 3rd Sriwijaya University Language and Education International Conference, 2018.

[3] M. A. Titaley, "Designing a book on illustration of the Majalengkan Sampyong art," (Thesis), Universitas Pasundan, 2018.

[4] S. Kolay, "Cultural heritage preservation of traditional Indian art through virtual new-media," Procedia - Social and Behavioral Sciences, vol. 22, no. 5, pp. 309-320, 2016.

[5] N. S. Murni, I. N. Kanca, D. M. S. Antara, "Local cultural conservation to support sustainable tourism in Kuta tourist area local cultural conservation to support sustainable tourism in Kuta tourist area," In Journal of Physics: Conference Series, pp. 1-6, 2018.

[6] R. Muhammad, M. S. M. Zahari, K. M. Abdullah, M. Sharif, "Young generation practices on Malaysian ethnic festival foodways," Procedia - Social and Behavioral Sciences, vol. 17, pp. 300-307, 2015.

[7] C. Grant, "Learning and teaching traditional music in Cambodia: Challenges and incentives," International Journal of Music Education, vol. 35, no. 1, pp. 5-16, 2017.

[8] Hidalgo, B. E. Fernández, F. J. G. Adell, E. M. Cano, M. T. Pérez, "Heritage higher education for senior citizens: The value of university for elderly towards social appropriation of cultural heritage," In ICERI2019, pp. 3396-3402, 2019.

[9] Nurhayati, Subadiyono, D. Suhendi, "The Dulmuluk traditional performing art: Revitalization and students' appreciation," Litera Jurnal Penelitian Bahasa, Sastra, Dan Pengajarannya, vol. 14, no. 2, pp. 229-238, 2015.

[10] M. Horsley, B. Knight, H. Huntly, "The role of textbooks extbooks and other teaching and learning resources in higher education in Australia: Change and continuity in supporting learning," IARTEM E-Journal, vol. 3, no. 2, pp. 43-61, 2010.

[11] S. Kasmaienezhadfard, M. Pourrajab, M. Rabbani, "Effects of pictures in textbooks on students," Multi-Disciplinary Edu Global Quest (Quarterly), vol. 4, 2015.

[12] T. Nagaoka, "Preserving and revitalizing traditional cultures and historical heritage in the Pacific Islands," ICH Courier, vol. $25,2015$.

[13] D. T. Irafahmi, D. M. Nuris, F. Zahroh, P. M. Nagari, "Critical thinking in accounting textbooks," Journal of Education and Learning (EduLearn), vol. 12, no. 1, pp. 2129, 2018.

[14] Nurhayati, Purnomo, M. E., Subadiyono, \& Meidarini, S., "Developing module 'Experts in dulmuluk performance' in university students," In ISLLE 2017: The 1st International Seminar on Language, Literature and Education, pp. 202211,2018

[15] S. Hendri, S. Anwar, "A development of integrated-science material development method," Journal of Educational Science and Technology, vol. 5, no. 2, pp. 130-139, 2019.

[16] S. Kusmana, J. Wilsa, Astiwati, "Development of poetry teaching materials based on creative process," International 
Journal of Education and Teaching, vol. 4, no. 1, pp. 155-167, 2020.

[17] D. K. Nazila, A. Adisaputra, A. Saragih, "Development of teaching material for short story writing experience based on $7^{\text {th }}$ grade students of Junior High School 2 Kajuruan Muda," Budapest International Research and Critics in Linguistics and Education, vol. 3, no. 2, pp. 1137-1150, 2020.

[18] A. Kukulska-Hulme, "Learning cultures on the move: Where are we heading?," Journal of Educational Technology and Society, vol. 13, no. 4, pp. 4-14, 2010.

[19] N. Mohammadi, V. Ghorbani, F. Hamidi, "Procedia computer effects of e-learning on language learning," Procedia Computer Science, vol. 3, pp. 464-468, 2011.

[20] M. Simuforosa, "The impact of modern technology on the educational attainment of adolescents," International Journal of Education and Research, vol. 1, no. 9, pp. 1-8, 2013.

[21] Nurhayati, M. E. Purnomo, Subadiyono, "The Dulmuluk performing art: An effort to integrate local culture into literary study," International Seminar and Annual Meeting 2016 BKS-PTN Wilayah Barat on Language, Literature, Art, and Culture Proceeding, pp. 549-556, 2016.

[22] E. S. Rice, E. Haynes, P. Royce, S. C. Thompson, "Social media and digital technology use among indigenous young people in Australia: A literature review," International Journal for Equity in Health, vol. 15, pp. 1-16, 2016.

[23] M. R. Ahmadi, "The impact of motivation on reading comprehension," International Journal of Research in English Education (IJREE), vol. 3, no. 2, pp. 116-125, 2018.

[24] A. Esfijani, B. E. Zamani, "Factors influencing teachers' utilization of ICT: The role of in-service training courses and access," Research in Learning Technology, vol. 28, pp. 1-16, 2020.

[25] Nurhayati, M. E. Purnomo, Subadiyono, "Impact of e-learning based online peer editing on Dulmuluk drama script writing," KBSP V National Seminar Proceedings, pp. 20-28, 2018.

[26] R. E. Osborne, P. Kriese, J. M. Davis, "It can be taught: Explorations into teaching the foundations for multicultural effectiveness in an online course," MERLOT Journal of Online Learning and Teaching, vol. 9, no. 4, pp. 534-545, 2013.
[27] T. Y. Aikina, O. M. Zubkova, "Integrating online services into English language teaching and learning: The case of Voki," pp. 66-68, 2015.

[28] M. Hajebi, M. Taheri, F. Fahandezh, H. Salari, "The role of web-based language teaching on vocabulary retention of adult pre-intermediate EFL learners," Journal of Language Teaching and Research, vol. 9, no. 2, pp. 372-378. 2018.

[29] T. Plomp, "Educational design research: An introduction," In T. Plomp \& N. Nieveen (Eds), An introduction to educational design research, Enschede: Netherlands Institute for Curriculum Development (SLO), pp. 9-36, 2013.

[30] M. Tessmer, Planning and conducting formative evaluations: Improving the quality of education and training (Digital Pr), Routledge, Abingdon, 2005.

[31] D. Oktaria, Z. Zulkardi, S. Somakim, "Developing derivative teaching material website for improving students' interest," Jurnal Kependidikan, vol. 43, no. 2, pp. 107-115, 2013.

[32] L. H. Munteanu, G. Gorghiu, L. M. Gorghiu, "The Role of New Technologies for Enhancing Teaching and Learning in Arts Education," Procedia - Social and Behavioral Sciences, vol. 122. pp. 245--249, 2014.

[33] H. Arsham, "Impact of the internet on learning and teaching," USDLA Journal: A Refereed Journal of The United States Distance Learning Association, vol. 16, no. 3, 2002.

[34] F. Bordbar, The Effectiveness of Website Design in Higher Education Recruitment, Southern Utah University, 2016.

[35] R. Garett, J. Chiu, L. Zhang, S. D. "Young, A literature review: Website design and user engagement," J Commun Media Technol, vol. 6, no. 3, pp. 1-14, 2016.

[36] S. S. Aljraiwi, "The effect of classroom web applications on teaching, learning and academic performance among college of education female students," Journal of Education and Learning, vol. 6, no. 2, pp. 132-145, 2017.

[37] Y. Kim, J. Kim, M. Li, "Web-enhanced teaching and learning vehicle preference in landscape architecture construction studio courses," Journal of E-Learning and Higher Education, pp. 1-8, 2015. 